Date of Publication: 27 May 2014

\section{Cunninghamia}

A journal of plant ecology for eastern Australia
\&Domain Trust

ISSN $0727-9620$ (print) • ISSN 2200-405X (Online)

\title{
Ecology of Eucalyptus aquatica (Myrtaceae), a restricted eucalypt confined to montane swamp (fen) habitat in south-eastern Australia
}

\author{
${ }^{1}$ John Shepherd and ${ }^{2}$ Vanessa Keyzer \\ ${ }^{1}$ Landcare Convenor, Penrose Swamps Conservation Group; Email: jsh95062@bigpond.net.au; \\ ${ }^{2}$ Regional Landcare Facilitator, Greater Sydney Local Land Services; Email: vanessa.keyzer@1ls.nsw.gov.au
}

\begin{abstract}
The Paddys River Wetlands in the New South Wales Southern Highlands, southwest of Sydney, are characterised by several watercourses with associated swamps (fens), some of which, on Forestry Corporation of NSW land, have been the focus for removal of Pinus radiata wildings by the Penrose Swamps Conservation Group. In this study we map a population of Eucalyptus aquatica trees in one of these swamps perched above Paddys River (latitude $34.65575^{\circ} \mathrm{S}$, longitude $150.21831^{\circ} \mathrm{E} ; 600 \mathrm{~m}$ elevation). Eucalyptus aquatica is geographically restricted to the Paddys River area and is listed as a threatened species at state and national levels. New findings on the physical characteristics of the swamp in relation to the bedrock geology, stream geomorphology, peat development and the main native plant species, are presented.

The occurrence of clumps of Eucalyptus aquatica appears to be independent of the type or thickness of the growing substrate. Rather it is suggested that a continuous supply of water and the shelter afforded by the narrow valley may be key factors determining the distribution of the trees at the study site. An on-going programme of research is underway to study other occurrences of Eucalyptus aquatica.
\end{abstract}

Keywords: montane swamp, threatened species, peat depth, incised watercourse, Hawkesbury Sandstone.

Cunninghamia (2014) 14: 63-76

doi:10.7751/cunninghamia.2014.14.004

\section{Introduction}

Eucalyptus aquatica (Broad-leaved Sally) (family Myrtaceae) is a small tree known only from the Penrose area in the Southern Highlands of New South Wales where it occurs sporadically in swampy ground (Harden 1991; Benson \& McDougall 1998; Australian Government 2008; NSW Office of Environment \& Heritage 2012). Previously considered a sub-species of Eucalyptus camphora (Brooker \& Kleinig, 1999), Eucalyptus aquatica was described as a separate species by Wiecek (2011). It is listed as aVulnerable Species under both NSW State and Federal threatened species legislation (Australian Government 2008; NSW
Office of Environment \& Heritage 2012). The swamp (fen) habitats associated with Eucalyptus aquatica are also listed as Endangered Ecological Communities "Temperate Highland Peat Swamps on Sandstone" under the Federal Environment Protection and Biodiversity Conservation Act 1999 (Australian Government 2005) and "Montane Peatlands and Swamps of the New England Tableland, NSW North Coast, Sydney Basin, South East Corner, South Eastern Highlands and Australian Alps bioregions" under the NSW Threatened Species Conservation Act 1995 (NSW Scientific Committee 2004). 
This study focuses on a local population of Eucalyptus aquatica in an (unnamed) montane swamp at $600 \mathrm{~m}$ altitude in Penrose State Forest, Penrose ( latitude -34.656 E, longitude 150.218 S decimal degrees) (Figure 1). We have also recorded Eucalyptus aquatica in Hanging Rock Swamp, Stingray Swamp and a number of unnamed swamps on the valley sides of Paddys River within and around Penrose State Forest. The montane swamp habitat has been described as a peat forming fen (see Mactaggart, 2008; Keith, 2004 p.210; Kodela 1994; NSW Office of Environment \& Heritage, undated) and a study of lower elevation but similar 'upland swamps or dells' on the Woronora Plateau near Wollongong (Young, 1982) suggested that these communities result from reduced permeability in some of the Hawkesbury Sandstone strata. The vegetation in all these swamps as typically treeless being dominated by shrubs and sedges, and the occurrence of a swamp-dependent eucalypt is quite unusual.

Like many threatened species, little is known of the ecology of Eucalyptus aquatica. Since 2008 Penrose Swamps Conservation Group has been working in Penrose State Forest removing weeds (predominately Pinus radiata wildings) and studying the factors influencing the occurrence of Eucalyptus aquatica in the swamps. This paper provides information on the distribution and occurrence of a local population and places the species' ecology into a geological and geomorphological context.

\section{Methods}

\section{Swamp setting}

The swamp studied is an (unnamed) montane swamp in Flora Reserve No. 97556 of Penrose State Forest, Penrose in the NSW Southern Highlands, southwest of Sydney (Figure 1 ). The State Forest is managed for softwood pine (Pinus radiata) production by Forestry Corporation of NSW. The swamp is bordered by a public road on two sides and is crossed by a forestry track (known as Webbers Road) at its western end (Figure 1).

The swamp is located on a tributary of Paddys River (latitude $34.65575^{\circ} \mathrm{S}$, longitude $150.21831^{\circ} \mathrm{E}$ ) (Figure 1), two kilometres to the south of Stingray Swamp. It is perched above the river and has a total length of approximately $1500 \mathrm{~m}$ (Figure 2). The lowermost $200 \mathrm{~m}$ segment of the swamp contains the Eucalyptus aquatica population, below Webbers Road and before the watercourse joins Paddys River. Surrounding vegetation includes mature Pinus radiata plantations and Eucalypt woodland (Figure 1). The site occurs within the Moss Vale 1:100,000 map sheet area.

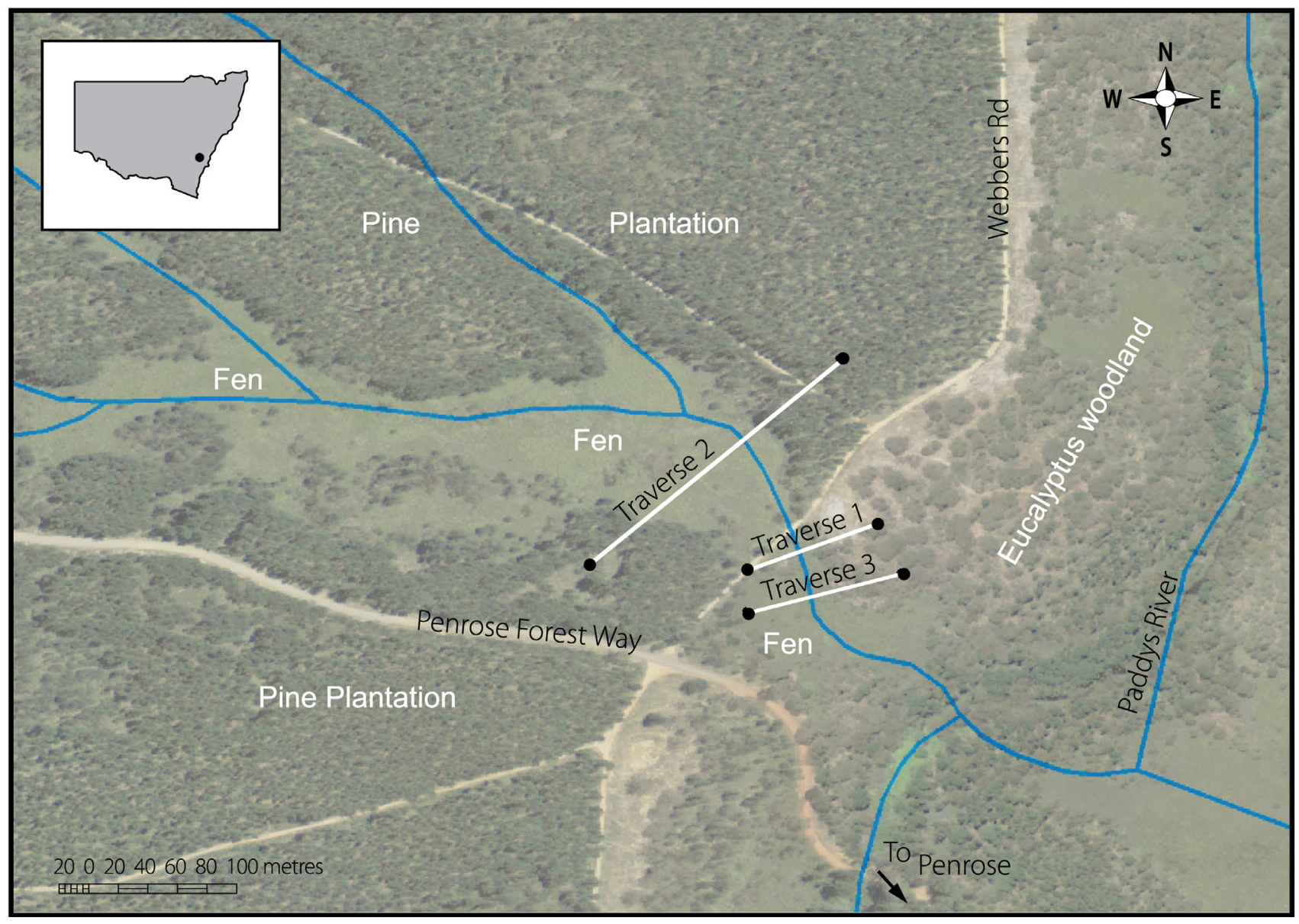

Fig. 1. Location of swamp study area in Flora Reserve, Penrose State Forest (including locality inset). Background imagery is ADS40 Moss Vale 1:100,000 (2008). 


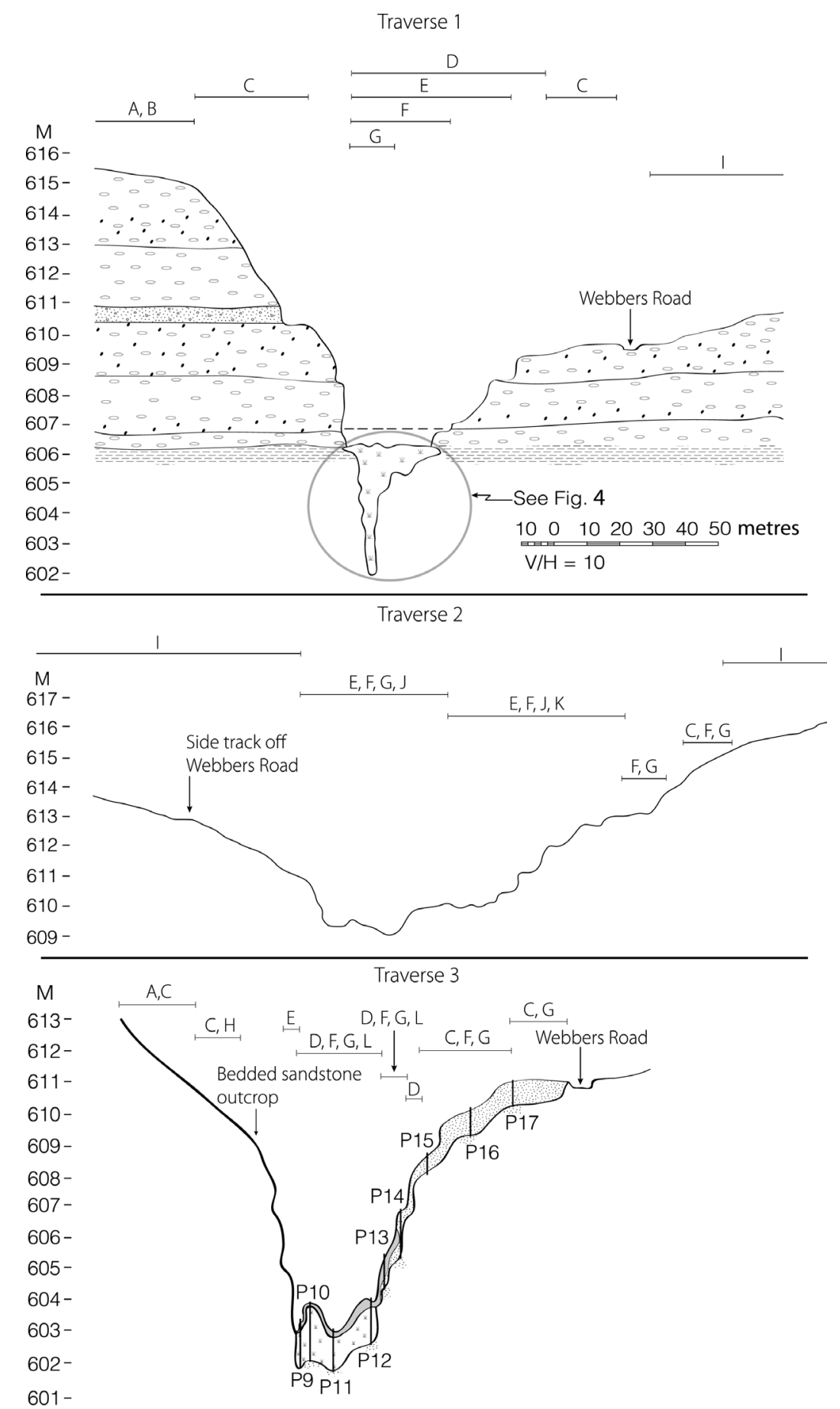

\begin{tabular}{|c|c|c|}
\hline \multicolumn{3}{|c|}{ LEGEND } \\
\hline  & $\begin{array}{l}\text { Coarse grained sand } \\
\text { Vegetation growing on top of peat } \\
\text { Probe holes P9 - P17 } \\
\text { Peat } \\
\text { Conglomerate } \\
\text { Coarse grained sandstone } \\
\text { Interbedded sandstone conglomerate } \\
\text { Claystone }\end{array}$ & $\begin{array}{l}\text { A - Eucalyptus piperita } \\
\text { B - Eucalyptus racemosa } \\
\text { C - Eucalyptus pauciflora } \\
\text { D - Eucalyptus aquatica } \\
\text { E - Gleichenia dicarpa } \\
\text { F- Chorizandra sphaerocphala } \\
\text { Gymnoschoenus sphaerocephalus } \\
\text { G- Leptospermum obovatum } \\
\text { Leptospermum juniperinum } \\
\text { H- Banksia spinulosa } \\
\text { I- Pine plantation } \\
\text { J- Hakea teretifolia } \\
\text { K- Xanthorrhoea concava } \\
\text { L- Sphagnum spp. }\end{array}$ \\
\hline
\end{tabular}

Fig. 2. Geological cross section of the gorge at Traverse 1 showing the deep, narrow peat deposit and occurrence of the main flora compared with cross section of Traverse 2 showing flora distribution, plus valley cross section of Traverse 3 showing peat deposits and flora distribution (Flora Reserve, Penrose State Forest). 


\section{Field mapping methods}

Fieldwork was carried out in August 2012. Our mapping focused on the lower segment of the swamp where Eucalyptus aquatica is located. The locations of the approximately 350 Eucalyptus aquatica plants that occur in the swamp along with associated vegetation were mapped using a hand held GPS. Tree height, canopy width, tree trunk type (single or mallee habit), percentage green foliage present and tree condition were estimated for each tree. Tree condition was estimated visually by the recorder based on percentage canopy alive, $($ dead $=0$, poor $=1-40 \%$, moderate $=41-$ $75 \%$, good $>75 \%$ ) to provide a baseline data set for future comparison (see Appendix 1).

Altitudinal data for each tree was taken at the top of the peat surface using an altimeter calibrated to a point of known nearby spot height on the Department of Lands 1:25 000 topographic sheet (2005), making it possible to measure altitudes to $\pm 1 \mathrm{~m}$. Frequent checks were made to ensure that the altimeter was only used in stable meteorological (pressure) conditions. Distance versus altitude profiles were constructed from field measurements.

A peat probe (a form of penetrometer), which extends to $5.2 \mathrm{~m}$, was used to map sandy horizons, peat type and peat depth, in some cases down to bedrock. The bedrock under the swamp peat was inferred from mapping in the valley sidewalls.
Three traverses (T1-T3) across the swamp were mapped on approximate bearings of $237^{\circ}(\mathrm{TN})$, that is, from $\mathrm{NE}$ to SW. Two of these (T1 and T3) were across the stands of Eucalyptus aquatica. T2 was made for comparison upstream of Webbers Road, across the treeless sedges (Figure 2). In addition, a longitudinal traverse was made from just below Webbers Road to the lowest extent of the swamp. Mapping in the swamp was arduous work due to dense vegetation and wet peat conditions.

\section{Results}

\section{Bedrock strata and geomorphologic features}

Limited rock outcrops of the mid Triassic age Hawkesbury Sandstone form bare ledges on the northern side of the swamp (Trigg \& Campbell 2011), whereas on the southern side sandstone benches are almost completely covered in vegetation (see Traverse 1 in Figure 1). This sandstone includes pebble conglomerates, inter-bedded and occasionally crossbedded with coarse grained sandstones. Clearly observed bedding planes separate the strata of different grain sizes. Just above the swamp level, at an elevation of 609-610 m, a thin shale/claystone lens is present; it outcrops in a small quarry exposure that is used for local road-base material.

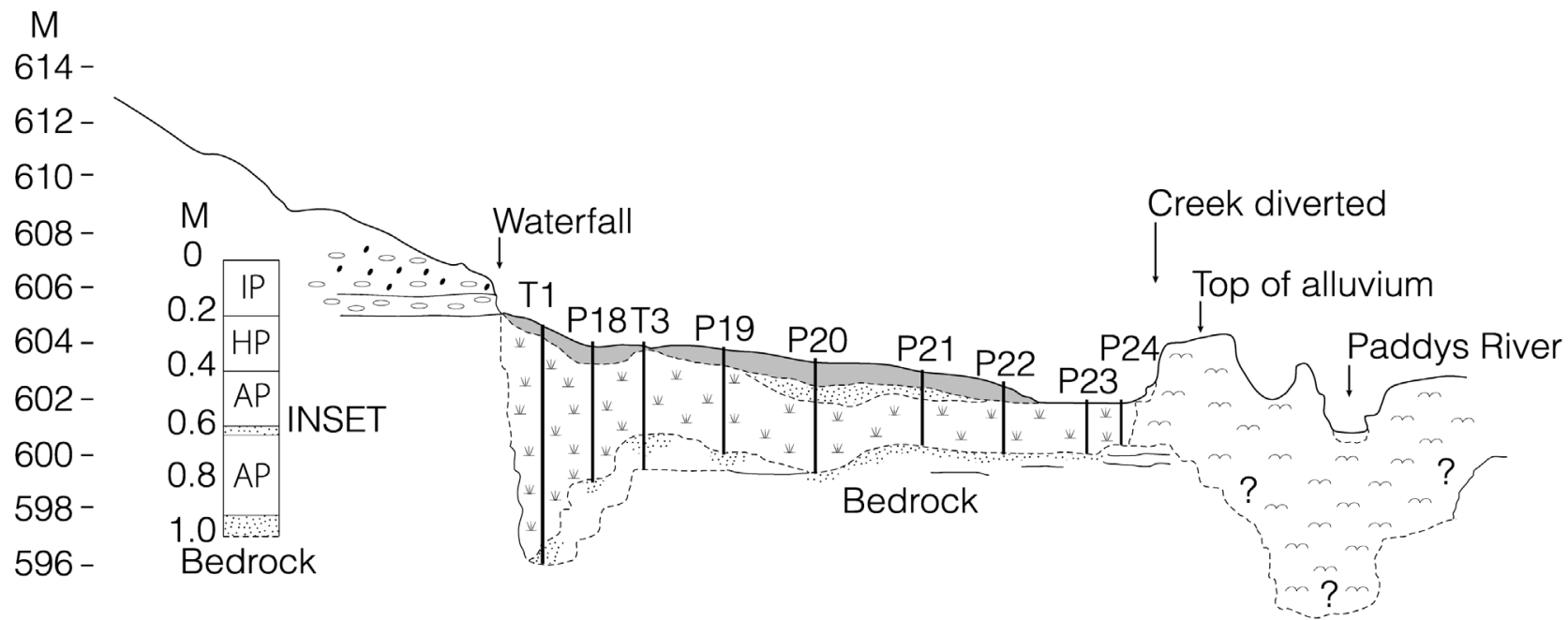

INSET: VERTICAL LOG OF TYPICAL PEAT SECTION (IP- FABRIC PEAT, HP- HEMIC PEAT, AP SAPRIC PEAT)

$\frac{20 \quad 0 \quad 20406080100 \text { metres }}{V / H=10}$

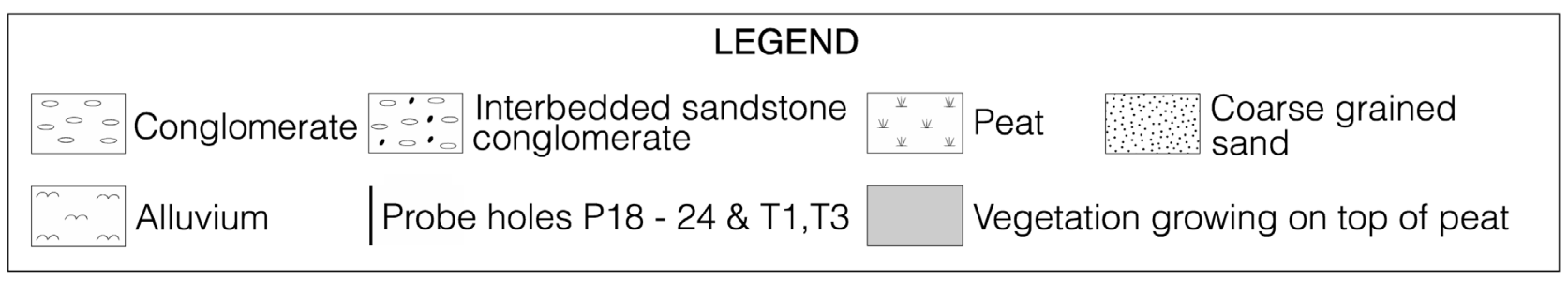

Fig. 3. Longitudinal section of the swamp showing the peat deposit and the fluvial deposits of Paddys River (Flora Reserve, Penrose State Forest). 

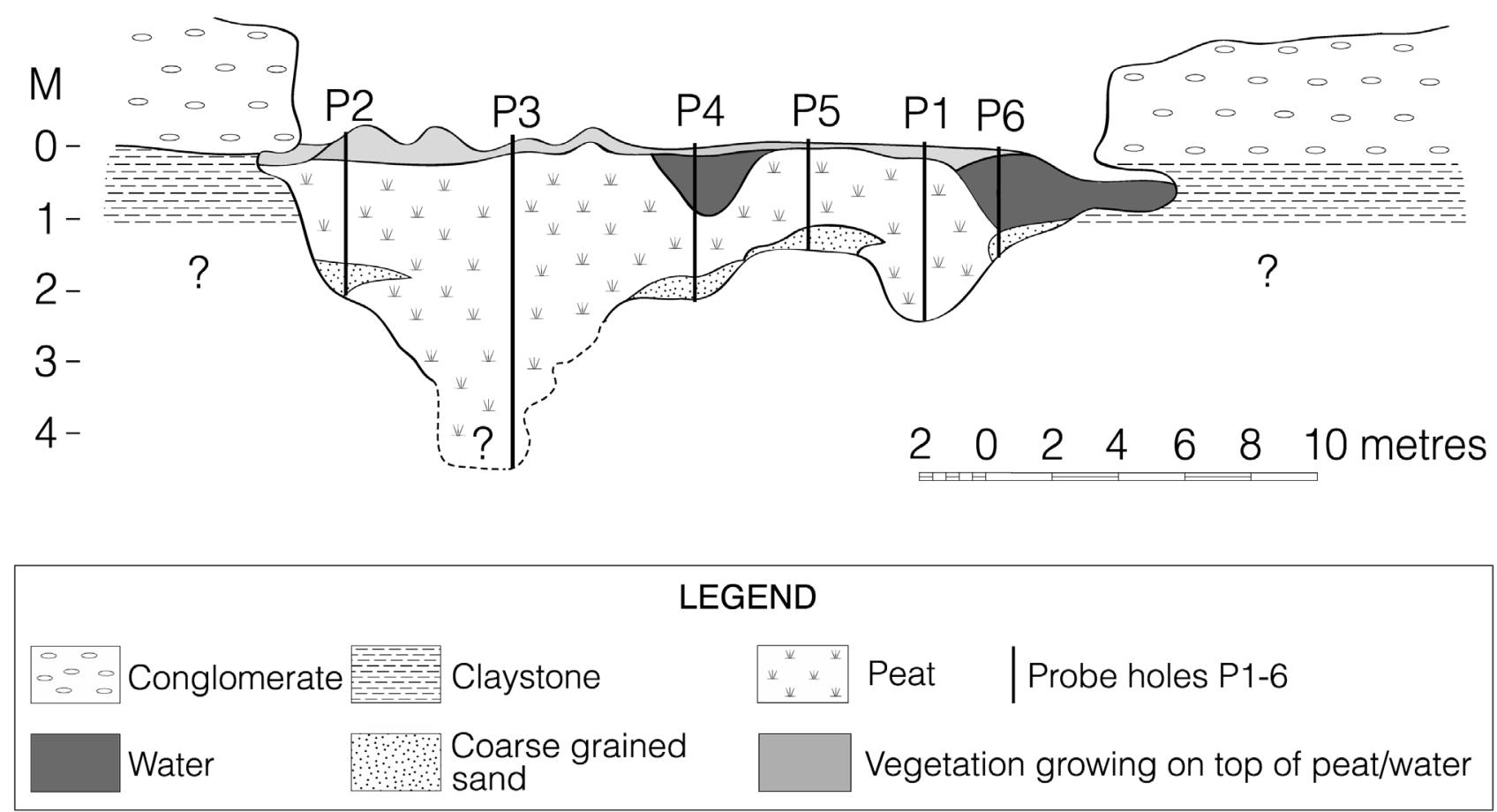

Fig. 4. Detailed cross section of the peat deposits along Traverse 1 (Flora Reserve, Penrose State Forest).

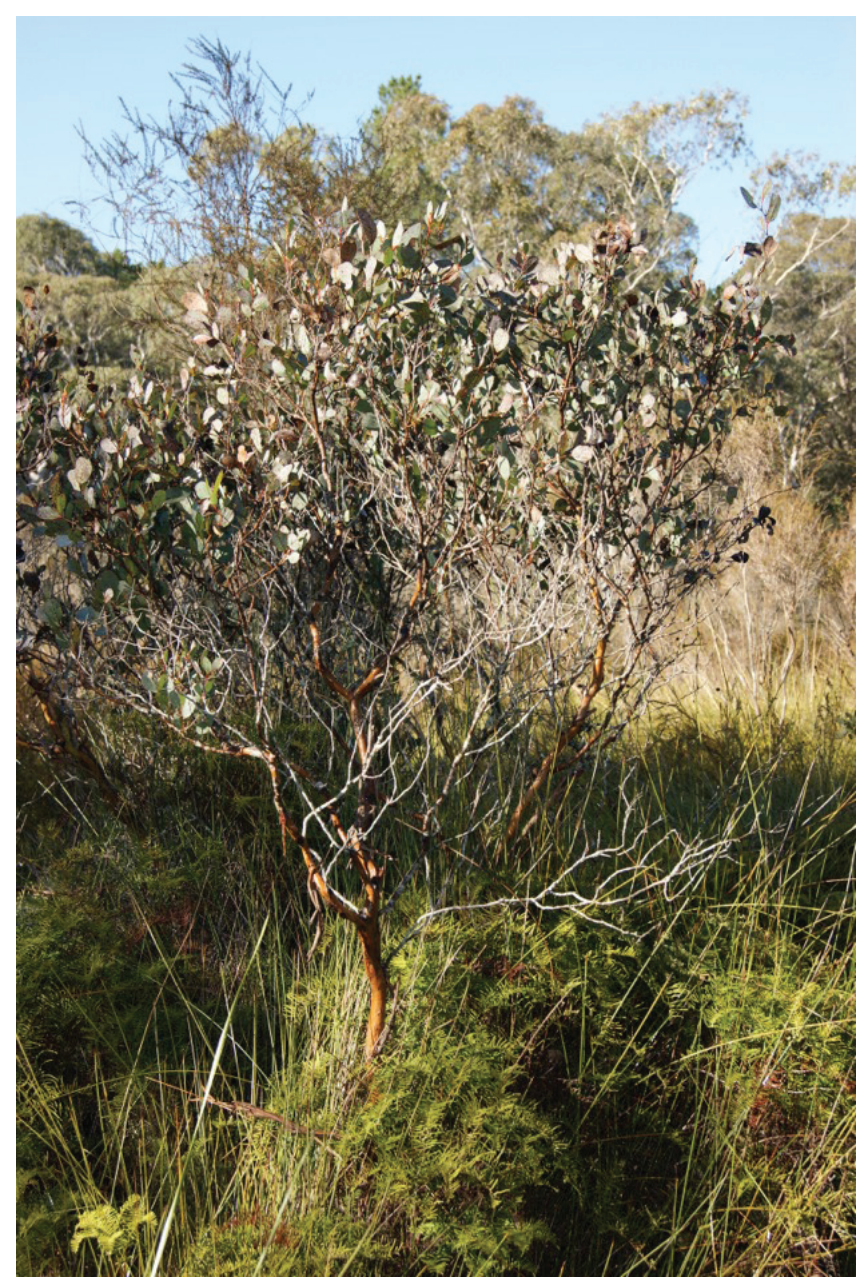

Fig. 5. View of the swamp showing Eucalyptus aquatica and associated plants (Flora Reserve, Penrose State Forest).
Below a hard conglomerate bed, there are overhangs above the swamp, indicating a weaker, possibly claystone bed and there is a small waterfall $0.75 \mathrm{~m}$ high, on this conglomerate bed. The valley cross section below the waterfall defines a gorge section of the watercourse and the waterfall is a primary knick point (Traverse 3 in Figure 2). Downstream in the swamp at Traverse 3, the valley is still in the form of an incised gorge with steep sides, but it widens out towards the bottom of the swamp (Figure 3). In contrast upstream of Webbers Road along Traverse 2, the valley is much wider with relatively gentle side slopes (Figure 1).

At the bottom of the swamp the watercourse turns abruptly $90^{\circ}$ into a southerly direction. At this location, shown in the long section (Figure 3), fluvial sand forms a barrier across to Paddys River. This feature is reminiscent of a flood plain levee type deposit and may indicate an older and elevated river channel (abandoned channel accretion) (Nanson \& Croke, 1992; see also Brierley \& Fryirs, 2005, Figure 4.6d). The swamp watercourse has been diverted by the levees and enters Paddys River downstream where the levee peters out above a river knick point.

\section{Nature of peat deposits}

The swamp occupies the organic-rich sediments of the drainage line and the accumulating materials represent peat (or organosol - Nat. Comm. on Soil and Terrain, 2009) of variable thickness above a basal sandy horizon on top of the Hawkesbury Sandstone bedrock. The top $200 \mathrm{~mm}$ of peat was sampled (5 tests) and found to have a $\mathrm{pH}$ of $6.0-6.5$ , characteristic of the more alkaline nature of a swamp (Mactaggart et al., 2008; Keith 2004 p.210). Below the waterfall knick point the peat reaches a maximum thickness 
of $4.2 \mathrm{~m}$ (Figure 4), thinning rapidly downstream to $<2 \mathrm{~m}$ and then tapering off towards the bottom of the swamp in a wedge-shaped profile (Figure 3). Between probe holes P19 to P22 there is a sandy deposit in the upper peat layers. A typical section in the thinner peat is shown in the inset of Figure 3. In most places there is $200-300 \mathrm{~mm}$ of fibric (fibrous) peat directly underneath the vegetation and this is underlain by hemic (semi-fibrous) and sapric (humified) peats (Nat. Comm. on Soil and Terrain, 2009). The latter is dark brown to black in colour and very wet. At the bottom of the swamp next to hole P24 the peat appears to overlay the sandy Paddys River fluvial deposits.

The thickest peat below the waterfall appears to be infilling a plunge pool cut, suggesting that the stream had much greater down cutting power in the past (Figure 3). On the valley sides above the peat there are thin sandy loams up to 750 mm thick covering the bedrock.

\section{Swamp vegetation}

Eucalyptus aquatica trees grow in association with sedge and shrub plants, mainly the tussock sedge Gymnoschoenus sphaerocephalus (Button grass) with Gleichenia dicarpa
(Pouched coral fern) and two species of Leptospermum, Leptospermum juniperinum (Prickly tea tree) and Leptospermum obovatum (Blunt leafed tea tree). The sedge and coral fern combine to form dense high mats of vegetation up to $1.6 \mathrm{~m}$, under the Eucalyptus aquatica trees (Figure 5). Sphagnum is also present in the swamp in the wettest areas, but generally limited in extent (in accord with the findings of Whinam and Chilcott, 2002). The overall health of Eucalyptus aquatica surveyed was good, with significant numbers of juveniles recorded (Appendix 1). However although Eucalyptus aquatica has been noted flowering (in January) and forming fruit, no small seedlings have been sighted, possibly due to the thick ground layer inhibiting recruitment.

\section{Eucalyptus aquatica distribution}

Dense clumps of Eucalyptus aquatica occur in wet deep peat below the waterfall, spanning the full gorge width (Figure 6). Clumps of up to 10 trees grow continuously along the main watercourse down to the bottom of the swamp to a point where the wet peat conditions appear to peter out. From the

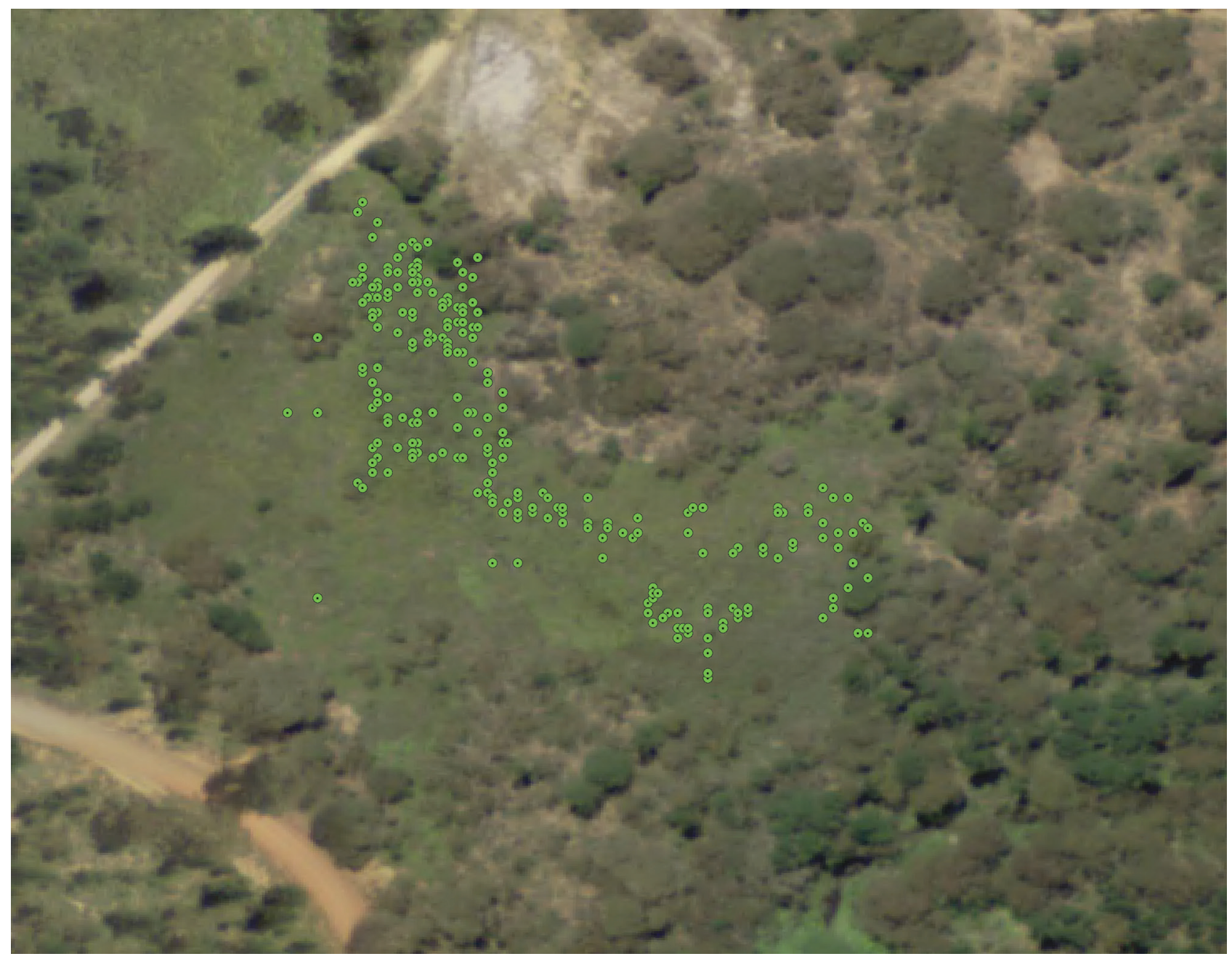

Fig. 6. Distribution of Eucalyptus aquatica in the swamp study area in August 2012 (Flora Reserve, Penrose State Forest). 
population of 350 trees, only 34 have mallee multistems visible through the ground layer.

On the southwestern edge of the swamp there are two clumps of Eucalyptus aquatica growing on sandstone ledges approximately $3 \mathrm{~m}$ higher than the current swamp peat level (Figure 6). These clumps contain up to 10 closely spaced trees, some only $1-1.5 \mathrm{~m}$ apart including several larger trees with heights of 4-6 m. Using the peat probe, it was found that these trees are growing in only 300-350 mm of sandy loam (not peat), directly on the bedrock (Figure 2). It is possible that these trees once occurred in peat that has now eroded away. Several isolated and elevated trees also occur in thin sandy peat less than $750 \mathrm{~mm}$ thick. There is a possibility that these clumps of trees are linked in the organosol by lignotubers as has been described for some Eucalypt species (Boland et al. 1984). Recent mapping in another nearby swamp (also perched above Paddys River) shows some denuded peat with clear lignotubers $(12-40 \mathrm{~mm}$ in diameter) connecting trees 1-2 m apart.

The height range for the majority of Eucalyptus aquatica trees is 2-5 m (details of individual trees are in Appendix 1). This range of heights and the presence of young trees at $<1.5$ $\mathrm{m}$ indicates that the population is currently stable (Figure 7). Common stem diameters are in the range $30-75 \mathrm{~mm}$; the largest recorded is $190 \mathrm{~mm}$. Stems are round and sinuous with abundant strips of loose bark present. Fruit and seed are present but we have not carried out any germination trials (a

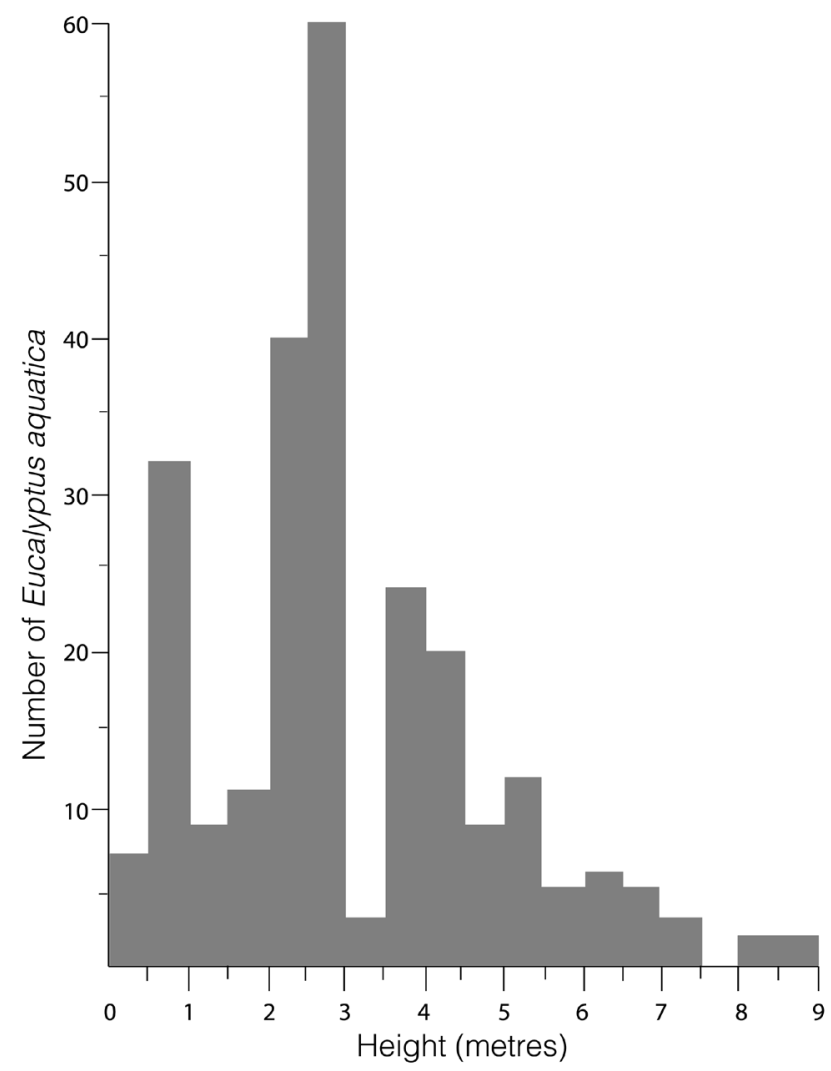

Fig. 7. Histogram of tree heights of Eucalyptus aquatica population $(n=350)$ swamp study area (Flora Reserve, Penrose State Forest). voucher specimen with fruit attached collected by us from Stingray Swamp in 2011 has been retained at the National Herbarium of NSW).

Tree condition, estimated visually based on percentage canopy alive, revealed that the majority of trees were in good condition $(44 \%)$ or moderate condition $(30 \%)$; $24 \%$ were in poor condition and $2 \%$ of trees were dead (Appendix 1).

The altitudinal range of the Eucalyptus aquatica population measured was very limited; all individuals occurred between 600-609 m above sea level only. Eucalyptus aquatica trees have been recorded at elevations up to $625 \mathrm{~m}$ in nearby Stingray Swamp. The limited elevation range overall is due to the limited occurrence of its particular swamp habitats and their related landscape position.

\section{Discussion}

The natural habitat of Eucalyptus aquatica does not appear to depend only on peat deposits as trees were also found to be occurring in sandy loam. However, it may be that the trees occurring in sandy loam originally occurred in peat that has since eroded. Water and water flow may be the critical factors that define the current occurrence of Eucalyptus aquatica; this hypothesis could be tested with further hydrological study. The shelter provided by the confined valley may also be a key factor in the population's current distribution.

In our particular swamp, the Eucalyptus aquatica population has a clumped distribution, although we could not find any visual evidence of lignotubers. Other factors may be influencing this clumping habit, again possibly associated with moisture characteristics at the site, or local conditions at the time of seedling recruitment. Recent mapping in another swamp (also perched above Paddys River) has shown Eucalyptus aquatica trees with lignotubers.

The longevity of the trees is unknown but the population of Eucalyptus aquatica appears stable and in good health. Although current texts state that Eucalyptus aquatica is a tree to $7 \mathrm{~m}$, trees mapped in this study were as tall as 9 $\mathrm{m}$. How the species has responded to fire, particularly with respect to the last two major bushfires, reported by Forestry Corporation of NSW to have occurred in 1939 and 1965, is unknown.

This study raises numerous research questions regarding the occurrence of Eucalyptus aquatica in montane swamps. For example, is the present localised population a relic from past colder, wetter climates? It is also possible that the clumps of Eucalyptus aquatic presently located adjacent to, but not in, the swamp represent a previously larger extent of swamp, and together with the suggested prior plunge pool, implies past climatic variability.

Eucalyptus aquatica has also been identified at Hanging Rock Swamp, Stingray Swamp and a number of unnamed swamps on the valley sides of Paddys River within and around Penrose State Forest, but it is difficult to determine the importance of our population of 350 trees in regards to the total population of the species overall due to a lack of data 
from other sites. Polygon mapping and numerical estimates of trees suggest a population of 750-1000 mature trees in Stingray Swamp. Mapping is also underway in additional areas to identify the extent of several smaller occurrences. This should provide an estimate of the total population of trees on which to base conservation assessment and prioritise particular conservation actions.

\section{Conservation \& Management}

Scant knowledge of the ecology of many threatened species hinders our efforts to protect and manage them. Eucalyptus aquatica appears to have a naturally restricted range and limited available habitat and for the species' continued survival the protection and management of the associated swamp and swamp habitat is necessary. Appropriate management recommendations include:

An effective buffer zone should be placed around these swamps to protect them from forestry actions. Smith \& Smith (2010) suggest a buffer of $60 \mathrm{~m}$ to protect significant native vegetation in the Blue Mountains region and this could be used as a guide for the Penrose Swamps;

Management should consider factors that might impinge on the current hydrology of these sites and this might include rerouting of existing vehicle tracks e.g. between the existing swamp crossing and Penrose Forest Way (Webbers Rd); as well as restricting public access to minimise impacts from four-wheel driving and rubbish dumping;

Management should also consider the installation of relevant signage highlighting the importance of the high conservation value of the swamps and the possible penalties applicable if damage should occur;

The upper portion of this swamp system has degraded, and contains dense stands of Pinus radiata wildings requiring active management and potentially the re-planting of native species. The establishment of Pinus radiata in the swamp could have negative effects through shading and competition on native species and on the hydrology, and hence persistence of Eucalyptus aquatica at this site.

\section{Acknowledgements}

We thank Daniel Anderson, now at the Glenelg Environmental Trust (SA), for early assistance and encouragement for this study. Susan Barker, Jenny Shepherd and Jason Trenwith also assisted in the field. Jason Trenwith is especially thanked for computer drafting of the cross section figures. Thanks also to Russell Moule of Wingecarribee Shire Council for help with plant identification. Dr. Sandy Berry is thanked for initial reviews of the manuscript.

\section{References}

Australian Government (2008) Approved Conservation Advice, Eucalyptus aquatica (Mountain Swamp Gum) for s266B of the EPBC Act, 1999. URL: http://www.environment.gov.au/ biodiversity/threatened/species/pubs/56173 (pdf.)

Australian Government (2005) Temperate Highland Peat Swamps on Sandstone: Advice to the Minister for the Environment and Heritage from the Threatened Species Scientific Committee (TSSC) on amendments to the List of Ecological Communities under the Environment Protection and Biodiversity Conservation Act 1999 (EPBC Act). URL: http://www.environment.gov.au/ biodiversity/threatened/communities/temperate-highland-peatswamps.html

Benson D. \& McDougall L. (1998) Ecology of Sydney plant species, Part 6 Dicotyledon family Myrtaceae. Cunninghamia 5(4): 868.

Boland D.J; Booker M.I.H.; Chippendale G.M.; Hall N.; Hyland B.P.M.; Johnston R.D.; Kleinig D.A. \& Turner J.D. (1984) Forest Trees of Australia. CSIRO, Melbourne.

Brierley G.J. \& Fryirs K.A. (2005) Geomorphology and river management: Applications of the River Styles Framework. Blackwell Publishing, chapter 4, River Character, 79-142.

Brooker M.I.H. \& Kleinig D.A. (1999) Field guide to Eucalypts Volume 1, South-Eastern Australia. Blooming Books, Hawthorn.

Department of Lands NSW (2005) Wingello Topographic and Orthophotomap 1:25000 sheet 8928-4S.

Harden, G. (ed.) (1991) The Flora of New South Wales, Volume 2. University of New South Wales Press, Sydney.

Keith D. (2004) Ocean shores to desert dunes: the native vegetation of New South Wales and the Australian Capital Territory. NSW Dept of Environment and Conservation, Sydney.

Kodela PG, James TA \& Hind PD (1994) Observations on the ecology and conservation status of the rare herb Gentiana wingecarribiensis, Cunninghamia 3(3): 535-541.

McDonald R.C. \& Isbell R.F. (2009) Soil Profile. In: The National Committee on Soil and Terrain, Australian Soil and Land Survey Handbook $3^{\text {rd }}$ edition. CSIRO Publishing, Collingwood.

Mactaggart B, Bauer J, Goldney D \& Rawson A (2008) Problems in naming and defining the swampy meadow - an Australian perspective. Journal of Environmental Management 87: 461-473.

Nanson G.C. and Croke J.C. (1992) A genetic classification of flood plains. Geomorphology 4: 459-486.

NSW Scientific Committee (2004) Montane Peatlands and Swamps of the New England Tableland, NSW North Coast, Sydney Basin, South East Corner, South Eastern Highlands and Australian Alps bioregions - final determination. URL: http://www.environment.nsw.gov.au/determinations/ MontanePeatlandsEndSpListing.htm

Trigg S.J. \& Campbell L.M. (2011) Moss Vale 1:100 000 Geological sheet 8928. Geological Survey New South Wales, Maitland, Preliminary Geology 8 April 2011.

NSW Office of Environment \& Heritage (2012) Threatened Species Profile: Broad-leaved Sally. URL: http://www.environment. nsw.gov.au/threatenedspeciesapp/profile. aspx id=10283

NSW Office of Environment \& Heritage (undated) Montane Bogs and Fens. URL: http://www.environment.nsw.gov.au/ threatenedspeciesapp/VegClass.aspx?vegclassname=Montane + Bogs+and + Fens\&habitat $=\mathrm{C}$ 
Smith P. \& Smith J. (2010) Urban Edge Effects in the Blue Mountains New South Wales: implications for design of buffers to protect significant habitats, Pacific Conservation Biology 16: 92-100.

Wetland Care Australia (2008) Paddys River Wetland Management Plan, Hawkesbury Nepean Catchment Management Authority.

Whinam J \& Chilcott N. (2002) Floristic description and environmental relationships of sphagnum communities in NSW and the ACT and their conservation management. Cunninghamia 7(3): 463-500.

Wiecek B. (2011) Letter dated 21/10.11, enquiry \#16757 Eucalypt identification. National Herbarium of New South Wales, Royal Botanic Garden Sydney.

Young A.R.M. (1982) Upland swamps(dells) on the Woronora Plateau, New South Wales. Phd thesis, School of Geography, University of Wollongong 168p. URL: http://ro.uow.edu.au/ theses/261 (pdf)

Manuscript accepted 2 April 2014 


\section{Appendix 1. Location, elevation, tree height and tree condition data for individual Eucalyptus aquatica trees mapped within the Paddys River swamp study site (Flora Reserve, Penrose State Forest).}

Mapped in August 2012 using Google earth imagery (dated 24/10/2009) and a Garmin hand-held GPS to measure tree locations and a Suunto altimeter to measure elevations. Tree height estimated in metres; where trees are mapped in clusters the maximum height is recorded. Tree condition was estimated visually based on percentage of tree canopy alive: dead ( 0$)$, poor $(1-40 \%)$, moderate $(41-75 \%)$, good $(>75 \%)$.

Tree site \# No. of trees Latitude Longitude Elevation(m) Tree H(m) Tree condition assessment

\begin{tabular}{|c|c|c|c|c|c|c|}
\hline 1 & 1 & -34.65560 & 150.21811 & 606 & 6.5 & poor \\
\hline 2 & 1 & -34.65558 & 150.21812 & 606 & 3.5 & moderate, top $1.5 \mathrm{~m}$ dead \\
\hline 3 & 8 & -34.65562 & 150.21815 & 605 & 7 & moderate, dead in tops, live at half height \\
\hline 4 & 2 & -34.65565 & 150.21814 & 604 & 6 & good \\
\hline 5 & 1 & -34.65567 & 150.21820 & 602 & 3 & moderate, reshooting at half height \\
\hline 6 & 1 & -34.65566 & 150.21822 & 603 & 3 & poor, leaning over \\
\hline 7 & 1 & -34.65569 & 150.21819 & 603 & 3.5 & good \\
\hline 8 & 1 & -34.65567 & 150.21823 & 603 & 3.5 & poor, almost dead, next to a pine \\
\hline 9 & 1 & -34.65570 & 150.21823 & 604 & 4 & poor, green top only \\
\hline 10 & 1 & -34.65571 & 150.21822 & 604 & 3 & poor, green top only \\
\hline 11 & 1 & -34.65571 & 150.21823 & 604 & 3 & poor, green top only \\
\hline 12 & 1 & -34.65573 & 150.21823 & 604 & 3 & poor, green top only \\
\hline 13 & 1 & -34.65571 & 150.21823 & 604 & 2.5 & poor, green top only \\
\hline 14 & 1 & -34.65572 & 150.21822 & 604 & 2.5 & poor, green top only \\
\hline 15 & 1 & -34.65574 & 150.21823 & 604 & 4 & poor, green top only \\
\hline 16 & 1 & -34.65576 & 150.21826 & 604 & 4.5 & good \\
\hline 17 & 1 & -34.65576 & 150.21823 & 604 & 5 & moderate \\
\hline 18 & 1 & -34.65572 & 150.21819 & 604 & 3.5 & good \\
\hline 19 & 1 & -34.65571 & 150.21817 & 604 & 3 & good \\
\hline 20 & 1 & -34.65574 & 150.21815 & 604 & 3 & good \\
\hline 21 & 1 & -34.65572 & 150.21817 & 604 & 4 & moderate, green foliage to half height \\
\hline 22 & 1 & -34.65575 & 150.21815 & 604 & 2 & good \\
\hline 23 & 1 & -34.65577 & 150.21817 & 604 & 4 & good \\
\hline 24 & 1 & -34.65576 & 150.21817 & 604 & 2 & moderate,re-growing with a dead top \\
\hline 25 & 1 & -34.65577 & 150.21814 & 604 & 3 & good \\
\hline 26 & 1 & -34.65577 & 150.21813 & 604 & 2.5 & good \\
\hline 27 & 1 & -34.65571 & 150.21812 & 605 & 4 & moderate \\
\hline 28 & 1 & -34.65573 & 150.21812 & 605 & 3 & moderate \\
\hline 29 & 1 & -34.65574 & 150.21811 & 605 & 3 & dead \\
\hline 30 & 1 & -34.65575 & 150.21814 & 605 & 5.5 & moderate \\
\hline 31 & 1 & -34.65574 & 150.21810 & 605 & 6.5 & moderate \\
\hline 32 & 4 & -34.65578 & 150.21812 & 604 & 5 & moderate \\
\hline 33 & 1 & -34.65577 & 150.21815 & 604 & 2.5 & good \\
\hline 34 & 1 & -34.65580 & 150.21815 & 604 & 3.5 & good \\
\hline 35 & 1 & -34.65583 & 150.21815 & 604 & 3 & good \\
\hline 36 & 1 & -34.65580 & 150.21814 & 604 & 3.3 & good, but a dead top \\
\hline 37 & 1 & -34.65581 & 150.21814 & 604 & 2 & good \\
\hline 38 & 1 & -34.65584 & 150.21819 & 605 & 4 & moderate \\
\hline 39 & 1 & -34.65580 & 150.21820 & 605 & 4 & good \\
\hline 40 & 1 & -34.65581 & 150.21822 & 606 & 2 & good \\
\hline 41 & 1 & -34.65580 & 150.21822 & 606 & 4.5 & moderate \\
\hline 42 & 1 & -34.65575 & 150.21819 & 606 & 2 & dead \\
\hline 43 & 1 & -34.65574 & 150.21822 & 606 & 3 & moderate \\
\hline 44 & 1 & -34.65574 & 150.21825 & 607 & 4.5 & moderate \\
\hline 45 & 1 & -34.65577 & 150.21829 & 607 & 1 & good \\
\hline 46 & 1 & -34.65576 & 150.21826 & 607 & 2 & moderate \\
\hline 47 & 1 & -34.65578 & 150.21829 & 607 & 3 & poor \\
\hline 48 & 1 & -34.65578 & 150.21828 & 607 & 2 & poor, new growth from dead trunk \\
\hline 49 & 1 & -34.65579 & 150.21831 & 605 & 1.2 & good \\
\hline 50 & 1 & -34.65582 & 150.21831 & 605 & 2 & good \\
\hline
\end{tabular}


Tree site \# No. of trees Latitude

\begin{tabular}{|c|c|c|}
\hline 51 & & \\
\hline 52 & & \\
\hline 53 & & \\
\hline 54 & & \\
\hline 55 & & \\
\hline 56 & & \\
\hline 57 & & \\
\hline 58 & & \\
\hline 59 & & \\
\hline 60 & & \\
\hline 61 & & \\
\hline 62 & & \\
\hline 63 & & \\
\hline 64 & & \\
\hline 65 & & \\
\hline 66 & & \\
\hline 67 & & \\
\hline 68 & & \\
\hline 69 & & \\
\hline 70 & & \\
\hline 71 & & \\
\hline 72 & & \\
\hline 73 & & \\
\hline 74 & & \\
\hline 75 & & \\
\hline 76 & & \\
\hline 77 & & \\
\hline 78 & & \\
\hline 79 & & \\
\hline 80 & & \\
\hline 81 & & \\
\hline 82 & & \\
\hline 83 & & \\
\hline 84 & & \\
\hline 85 & & \\
\hline 86 & & \\
\hline 87 & & \\
\hline 88 & & \\
\hline 89 & & \\
\hline 90 & & \\
\hline 91 & & \\
\hline 92 & & \\
\hline 93 & & \\
\hline 94 & & \\
\hline 95 & & \\
\hline 96 & & \\
\hline 97 & & \\
\hline 98 & & \\
\hline 99 & & \\
\hline 100 & & \\
\hline 101 & & \\
\hline 102 & & \\
\hline 103 & & \\
\hline 104 & & \\
\hline 105 & & \\
\hline 106 & & \\
\hline 107 & & \\
\hline 108 & & \\
\hline 109 & & \\
\hline 110 & & \\
\hline
\end{tabular}

\section{Longitude}

\section{$-34.65582$}

$-34.65579$

$-34.65582$

$-34.65584$

$-34.65583$

$-34.65585$

$-34.65585$

$-34.65585$

$-34.65585$

$-34.65586$

$-34.65584$

$-34.65587$

$-34.65586$

$-34.65592$

$-34.65591$

$-34.65591$

$-34.65594$

$-34.65596$

$-34.65601$

$-34.65599$

$-34.65598$

$-34.65597$

$-34.65602$

$-34.65601$

$-34.65602$

$-34.65602$

$-34.65600$

$-34.65600$

$-34.65603$

$-34.65608$

$-34.65609$

$-34.65609$

$-34.65609$

$-34.65606$

$-34.65606$

$-34.65608$

$-34.65607$

$-34.65609$

$-34.65607$

$-34.65606$

$-34.65610$

$-34.65608$

$-34.65609$

$-34.65612$

$-34.65612$

$-34.65614$

$-34.65615$

$-34.65600$

$-34.65600$

$-34.65566$

$-34.65570$

$-34.65569$

$-34.65572$

$-34.65573$

$-34.65575$

$-34.65578$

$-34.65580$

$-34.65579$

$-34.65582$

$-34.65580$

\subsection{1}

150.21832

150.21829

150.21832

150.21829

150.21828

150.21828

150.21803

150.21826

150.21825

150.21825

150.21822

150.21822

150.21812

150.21812

150.21815

150.21814

150.21815

150.21817

150.21814

150.21815

150.21817

150.21817

150.21820

150.21822

150.21823

150.21823

150.21826

150.21831

150.21828

150.21831

150.21832

150.21826

150.21823

150.21822

150.21823

150.21819

150.21815

150.21814

150.21815

150.21814

150.21822

150.21822

150.21817

150.21814

150.21811

150.21812

150.21803

150.21797

150.21825

150.21831

150.21835

150.21832

150.21834

150.21832

150.21834

150.21832

150.21828

150.21832

150.21835

\section{Elevation(m) Tree H(m) Tree condition assessment}

605
605
606
606
606
606
606
606
606

606

606

606

606

606

605

606

606

606

606

607

607

607

607

607

607

607

607

609

609

609

609

609

609

609

609

608

608

608

607

608

609

608

608

608

608

608

608

609

609

603

604

605

605

605

606

606

606

606

606

606
2

2.5

2.5

4

6

5

2

3

6.5

6.5

0.75

3

3.5

1

2.2

1.8

3

4

2.2

3.5

4

5

1

1.5

2.75

5

2.2

5

3

5

2.5

3.5

2.5

1.75

1.1

1.1

2

3.5

3.5

2.5

1.5

1

3.5

6

6

8

3.5

4

4.5

3.5

4

4.5

2.1

3.5

2.25

1.2

1.3

5.5

3 moderate
good
good
good
good
moderate
good
good
good
moderate
good
good
good
poor, but new green shoots
good moderate, dead in top

moderate, young tree dead in top good

moderate, brown growths

good

moderate, brown growths

poor, brown growths

good, leaning at $45 \mathrm{deg}$

good

good, young tree

poor, green top, brown growths poor, green top, brown growths poor, green top, brown growths poor ,green top, brown growths good

moderate, brown growths

poor

good

good

good

good, young tree

good, young tree

good, young tree

moderate

good

moderate

good, young trees

good, young trees

good, young trees

good, minor dead branches

good, minor dead branches

moderate

good, some brown growths

moderate, but new shoots

poor

good

poor

good

poor, green shoots at $1.2 \mathrm{~m}$ height

moderate

good

good

good

moderate, green at half height, dead top 
Tree site \# No. of trees Latitude

\begin{tabular}{|c|c|c|}
\hline 111 & 1 & -34.65583 \\
\hline 112 & 2 & -34.65583 \\
\hline 113 & 2 & -34.65585 \\
\hline 114 & 1 & -34.65588 \\
\hline 115 & 1 & -34.65588 \\
\hline 116 & 1 & -34.65586 \\
\hline 117 & 1 & -34.65587 \\
\hline 118 & 1 & -34.65588 \\
\hline 119 & 1 & -34.65588 \\
\hline 120 & 1 & -34.65588 \\
\hline 121 & 10 & -34.65590 \\
\hline 122 & 1 & -34.65592 \\
\hline 123 & 1 & -34.65599 \\
\hline 124 & 1 & -34.65592 \\
\hline 125 & 1 & -34.65597 \\
\hline 126 & 1 & -34.65596 \\
\hline 127 & 1 & -34.65594 \\
\hline 128 & 1 & -34.65600 \\
\hline 129 & 1 & -34.65600 \\
\hline 130 & 3 & -34.65608 \\
\hline 131 & 1 & -34.65604 \\
\hline 132 & 1 & -34.65601 \\
\hline 133 & 2 & -34.65607 \\
\hline 134 & 1 & -34.65604 \\
\hline 135 & 1 & -34.65606 \\
\hline 136 & 6 & -34.65609 \\
\hline 137 & 2 & -34.65606 \\
\hline 138 & 1 & -34.65610 \\
\hline 139 & 2 & -34.65612 \\
\hline 140 & 1 & -34.65614 \\
\hline 141 & 1 & -34.65616 \\
\hline 142 & 1 & -34.65616 \\
\hline 143 & 1 & -34.65617 \\
\hline 144 & 1 & -34.65618 \\
\hline 145 & 1 & -34.65616 \\
\hline 146 & 1 & -34.65617 \\
\hline 147 & 1 & -34.65618 \\
\hline 148 & 1 & -34.65620 \\
\hline 149 & 1 & -34.65621 \\
\hline 150 & 1 & -34.65616 \\
\hline 151 & 1 & -34.65620 \\
\hline 152 & 1 & -34.65620 \\
\hline 153 & 6 & -34.65616 \\
\hline 154 & 4 & -34.65619 \\
\hline 155 & 1 & -34.65630 \\
\hline 156 & 1 & -34.65630 \\
\hline 157 & 1 & -34.65621 \\
\hline 158 & 3 & -34.65617 \\
\hline 159 & 1 & -34.65619 \\
\hline 160 & 2 & -34.65620 \\
\hline 161 & 1 & -34.65622 \\
\hline 162 & 2 & -34.65619 \\
\hline 163 & 1 & -34.65622 \\
\hline 164 & 1 & -34.65623 \\
\hline 165 & 1 & -34.65617 \\
\hline 166 & 1 & -34.65622 \\
\hline 167 & 3 & -34.65623 \\
\hline 168 & 1 & -34.65623 \\
\hline 169 & 2 & -34.65625 \\
\hline 170 & 1 & -34.65629 \\
\hline
\end{tabular}

\section{Longitude}

150.21834

150.21835

150.21834

150.21832

150.21831

150.21829

150.21829

150.21829

150.21832

150.21831

150.21834

150.21837

150.21840

150.21837

150.21831

150.21840

150.21837

150.21834

150.21833

150.21837

150.21835

150.21837

150.21837

150.21840

150.21840

150.21840

150.21841

150.21838

150.21838

150.21837

150.21835

150.21837

150.21838

150.21838

150.21835

150.21843

150.21841

150.21840

150.21843

150.21843

150.21843

150.21846

150.21848

150.21846

150.21838

150.21843

150.21849

150.21849

150.21851

150.21852

150.21852

150.21852

150.21857

150.21861

150.21857

150.21861

150.21861

150.21857

150.21860

150.21860

\section{Elevation(m) Tree H(m) Tree condition assessment}

\section{5}

605

$$
605
$$

good

moderate
605

605

605

606

606

606

poor, green reshooting at half height

good

good

moderate

good

good

good,some brown growths

dead and brown growths

moderate, brown growths

good

poor, dead top, brown growths, shoots half height

dead

moderate, brown growths

good

good

good

dead

moderate, brown growths

good

moderate

good

moderate

poor

good, trees $1 \mathrm{~m}$ apart

poor, dead top reshooting at half height

poor, reshooting, brown clusters

poor, leaning, reshooting, brown growths

poor, reshooting

good

good, young tree

dead

poor

moderate

good, young tree

good, young tree

good, young tree

good, young tree

poor, brown growths

good, young tree, $100 \%$ good green foliage

good

poor, brown growths

good

moderate, dead top, reshooting at half height

good

good

moderate

good, young tree

moderate

good

poor, almost dead, reshooting at half height

good

good

poor, reshooting

poor, reshooting, brown growths

good

good

good

good 
Tree site \# No. of trees Latitude

$171 \quad 1 \quad-34.65624$

$172 \quad 1 \quad-34.65625$

$173 \quad 1 \quad-34.65624$

$174 \quad 1$

$175 \quad 1$

$176 \quad 1$

$177 \quad 3$

$178 \quad 5$

$179 \quad 1$

$180 \quad 1$

$\begin{array}{ll}181 & 1 \\ 182 & 1\end{array}$

$\begin{array}{ll}182 & 1 \\ 183 & 1\end{array}$

$184 \quad 1$

$185 \quad 1$

$186 \quad 1$

$187 \quad 1$

$188 \quad 2$

$189 \quad 2$

$190 \quad 1$

$191 \quad 1$

$192 \quad 3$

$193 \quad 1$

$194 \quad 1$

$195 \quad 7$

$196 \quad 1$

$197 \quad 1$

$198 \quad 1$

$199 \quad 2$

200

201

202

203

204

205

206

207

208

209

210

211

212

213

214

215

216

217

218

219

220

221

222

223

224

225

226

227

228

229

230
$-34.65621$

$-34.65624$

$-34.65620$

$-34.65628$

$-34.65628$

$-34.65619$

$-34.65619$

$-34.65627$

$-34.65628$

$-34.65628$

$-34.65629$

$-34.65619$

$-34.65625$

$-34.65627$

$-34.65627$

$-34.65626$

$-34.65620$

34.65620

$-34.65619$

$-34.65620$

$-34.65622$

$-34.65615$

$-34.65617$

$-34.65617$

$-34.65622$

$-34.65623$

$-34.65624$

$-34.65624$

$-34.65627$

$-34.65630$

$-34.65633$

$-34.65635$

$-34.65637$

$-34.65639$

$-34.65640$

$-34.65639$

$-34.65641$

$-34.65639$

$-34.65640$

$-34.65640$

$-34.65642$

$-34.65643$

$-34.65653$

$-34.65652$

$-34.65648$

$-34.65643$

$-34.65645$

$-34.65644$

$-34.65643$

$-34.65643$

$-34.65643$

$-34.65640$

$-34.65640$

$-34.65641$

$-34.65642$

$-34.65640$
$-34.65645$
Longitude

\subsection{4}

150.21866

150.21867

150.21867

150.21877

150.21877

150.21880

150.21880

150.21880

150.21878

150.21887

150.21886

150.21892

150.21895

150.21895

150.21904

150.21892

150.21898

150.21898

150.21896

150.21895

150.21901

150.21901

150.21904

150.21904

150.21906

150.21909

150.21912

150.21913

150.21910

150.21907

150.21907

150.21910

150.21913

150.21909

150.21803

150.21886

150.21889

150.21881

150.21887

150.21889

150.21887

150.21881

150.21884

150.21884

150.21881

150.21881

150.21881

150.21878

150.21881

150.21877

150.21875

150.21875

150.21876

150.21877

150.21875

150.21873

150.21872

150.21870

150.21869

\section{Elevation(m) Tree $\mathbf{H}(\mathrm{m}) \quad$ Tree condition assessment}

$\begin{array}{lll}601 & 1.1 & \text { good } \\ 601 & 1.5 & \text { good } \\ 601 & 1.5 & \text { good } \\ 601 & 1.1 & \text { good } \\ 603 & 2 & \text { good } \\ 602 & 1 & \text { good } \\ 602 & 2 & \text { moderate, brown growths } \\ 602 & 2.5 & \text { moderate } \\ 603 & 2.1 & \text { good } \\ 603 & 1 & \text { good } \\ 602 & 2 & \text { poor } \\ 602 & 1.2 & \text { good } \\ 602 & 1 & \text { good } \\ 603 & 3.5 & \text { poor, reshooting } \\ 603 & 8 & \text { moderate } \\ 603 & 3 & \text { poor } \\ 603 & 0.5 & \text { good } \\ 603 & 2.3 & \text { poor, reshooting from base } \\ 603 & 2.2 & \text { poor }\end{array}$

poor

poor

moderate

moderate

moderate

poor

poor, reshooting from base

poor

moderate

moderate

moderate

poor

moderate

moderate and brown growths

poor

poor

good

good

good, young tree

good

good

good

good

poor, reshooting

moderate

poor

poor

poor

poor

poor

moderate

moderate

good

good

good, young tree

good, young tree

good, young tree

good

moderate

poor, reshooting

good

poor, reshooting 


\section{Tree site \# No. of trees Latitude}

$231 \quad 2 \quad-34.65638$

$\begin{array}{lll}232 & 1 & -34.65637\end{array}$

233

234

235

236

237

238

239

240
-34.65637
-34.65635

$-34.65636$

$-34.65636$

$-34.65637$

$-34.65639$

$-34.65644$

$-34.65644$

$-34.65641$

\section{Longitude}

Elevation(m) Tree H(m)

$\begin{array}{ll}150.21869 & 606 \\ 150.21870 & 606 \\ 150.21870 & 606 \\ 150.21870 & 606 \\ 150.21871 & 606 \\ 150.21906 & 603 \\ 150.21906 & 603 \\ 150.21913 & 602 \\ 150.21911 & 602 \\ 150.21904 & 602\end{array}$

good, young tree

poor, brown growths

good, young tree

dead

good

moderate

moderate

moderate

moderate, reshooting

poor 